\title{
The Integration of Culture and Local Wisdom in Indonesian Language Teaching For TISOL
}

\author{
Yuyun Safitri ${ }^{1}$, Sarwiji Suwandi ${ }^{2}$, Herman J. Waluyo ${ }^{3}$, Muhammad Rohmadi ${ }^{4}$ \\ ${ }^{1234}$ Universitas Sebelas Maret, Surakarta \\ 1yusa020319@gmail.com
}

\begin{abstract}
Indonesia has various forms of culture and local wisdom that are spread throughout the region. Culture and local wisdom can be used as interesting teaching material. In this paper, we will explain the great potential of Indonesian culture and local wisdom which can support and support the implementation of Indonesian language learning for foreign students and also TISOL. The method used in this research is descriptive qualitative. The data collected in this paper is in the form of local culture and culture that can support Indonesian learning for foreign speakers as well as good responses from foreign speakers related to culture and local wisdom in Indonesia. The results of this study are in the form of exposure to the interest of foreign students in the form of culture and local wisdom in Indonesia. Indonesian language learning for foreign speakers will be more optimal and run smoothly by using cultural integration and local wisdom in Indonesia. Thus, students can understand Indonesian well and also learn to know Indonesia through diverse forms of local culture and wisdom.
\end{abstract}

Keywords: TISOL, culture, local wisdom, Indonesian language teaching

\section{PENDAHULUAN}

Education is Menteri Pendidikan dan Kebudayaan Republik Indonesia sudah menerbitkan peraturan yang mengatur tentang mekanisme pembelajaran bahasa Indonesia bagi penutur asing (BIPA). Sesuai dengan Permendikbud Nomor 27 Tahun 2017 yang mengatur bahwa Salah satu bidang yang mengembangkan Standar Kompetensi Lulusan ini adalah Bidang Bahasa Indonesia bagi Penutur Asing (BIPA)[1]. Ada perbedaan antara BIPA dengan bidang lainnya, yaitu peserta yang mengikuti kusus dan pelatihan ini. Peserta BIPA merupakan warga negara asing atau warga negara Indonesia yang tidak bisa berbahasa Indonesia. Peserta didik ini memelajari bahasa Indonesia untuk berbagai tujuan, di antaranya dapat berinteraksi dan berkomunikasi dengan menggunakan bahasa Indonesia, bukan untuk mendapatkan keahlian dalam bidang pekerjaan.

BIPA merupakan salah satu program pelatihan yang diperlukan dalam rangka peningkatkan fungsi bahasa negara sebagai bahasa internasional dan pemenuhan kebutuhan tenaga kerja asing akan program pelatihan bahasa Indonesia. Identifikasi kebutuhan pasar sangat diperlukan dalam persiapan kegiatan suatu program kursus atau pelatihan. Identifikasi kompetensi yang harus dimiliki oleh peserta didik BIPA juga diperlukan agar penyusunan standar kompetensi lulusan lebih terfokus. Terdapat tujuh (7) level kompetensi yang di 
dalamnya meliputi empat kemahiran berbahasa, yaitu mendengarkan, berbicara, membaca, dan menulis. Program kursus dan pelatihan BIPA merupakan program kursus dan pelatihan untuk menghasilkan lulusan yang terampil berbahasa Indonesia untuk berbagai tujuan dalam berbagai konteks yang sesuai dengan kompetensi masing-masing level.

Pembelajaran bahasa Indonesia dalam program BIPA harus dilakukan dengan baik untuk orang luar negeri yang akan belajar di Indonesia. Hal ini juga sesuai dengan peraturan yang berwujud Undang-Undang Republik Indonesia No. 12 tahun 2012 tentang implementasi pendidikan di universitas yang harus selaras dengan contoh dan budaya masyarakat bangsa[2]. Salah satu cara untuk menyelaraskan dengan budaya Indonesia adalah bahwa pelajar asing perlu mengajar dan memberikan pendidikan tentang bahasa Indonesia baik secara teoretis maupun praktis melalui pendidikan yang komprehensif dan berkelanjutan[3]. Itu juga mengacu pada posisi bahasa yang memiliki peran penting dalam kehidupan manusia, terutama dalam interaksi. Bahasa sebagai pengenal dan juga sebuah konektor digunakan oleh masingmasing individu untuk berinteraksi satu sama lain.

Budaya dan kearifan lokal yang ada di Indonesia mampu menjadi aspek pendukung dalam pembelajaran bahasa Indonesia melalui program BIPA. Keberadaan budaya dan kearifan lokal memberikan daya tarik yang lebih bagi mahasasiwa asing. Selain itu, mereka akan lebih antusias belajar bahasa Indonesia sekaligus mempelajari budaya Indonesia mengingat keberagaman budaya dan kearifan lokal Indonesia. Mahasiswa program BIPA memiliki pengalaman baru dengan lebih mengenal Indonesia dan budayanya. Kesadaran penutur asing terhadap budaya Indonesia dapat membantu penutur asing mengaktualisasikan diri mereka dengan baik dalam bahasa Indonesia[4]. Budaya mendukung penutur asing dalam menggunakan bahasa Indonesia sesuai dengan situasi dan kondisi masyarakat Indonesia yang beragam dan juga memiliki budaya yang kaya. Selain itu, memperkenalkan multikulturalisme Indonesia kepada penutur asing juga bisa menumbuhkan sikap positif dan apresiatif dari penutur asing terhadap kekayaan budaya Indonesia. Budaya Indonesia memainkan peran penting sebagai sarana untuk memfasilitasi siswa asing dalam belajar Bahasa Indonesia melalui program BIPA.

\section{METODE}

Penelitian ini merupakan penelitian kualitatif. penelitian kualitatif ini menggunakan strategi dan prosedur penelitian yang sangat fleksibel. Penelitian kualitatif menggunakan rancangan penelitian terbuka (emergent design) yang disempurnakan selama pengumpulan data[5]. Pendekatan penelitian yang digunakan dalam penelitian ini adalah deskriptif kualitatif. Penelitian kualitatif ini dilakukan untuk mendeskripsikan substansi isi mengenai keunggulan integrasi budaya dan kearifan lokal sebagai penunjuang pembelajaran Bahasa Indonesia bagi pebelajar BIPA. Teknik pengumpulan data pada penelitian ini menggunakan teknik observasi, analisis dokumen, dan studi pustaka. Kemudian, teknik analisis data dilakukan dengan cara pengumpulan data, reduksi data, penyajian data, dan penarikan simpulan.

\section{HASIL DAN PEMBAHASAN}

Pembelajaran bahasa Indonesia bagi penutus asing selalu dinamis dan menyesuaikan perkembangan zaman. Pembelajaran BIPA ini selalu mengalami perkembangan dan perubahan yang menyesuaikan dengan perkembangan zaman. Hal itu juga berdampak pada 
materi-materi kebahasaan dan ilustrasi-ilustrasi yang digunakan untuk menunjang pembelajaran bahasa Indonesia bagi mahasiswa BIPA. Tuntutan mengenai bahan ajar yang inovatif dan kreatif tidak bisa dihindari karena minat penutur asing untuk belajar bahasa Indonesia sangat tinggi. Untuk itu, penulis memiliki pemikiran bahwa dengan integrasi budaya dan kearifan lokal asli Indonesia mampu menunjuang proses pembelajaran bahasa Indonesia bagi BIPA. Budaya dan kearifan lokal merupakan identitas atau kepribadian budaya sebuah bangsa yang menyebabkan bangsa tersebut mampu menyerap, bahkan mengolah kebudayaan yang berasal dari luar/bangsa lan menjadi watak dan kemampuan sendiri[6]. Identitas dan Kepribadian tersebut tentunya menyesuaikan dengan pandangan hidup masyarakat sekitar agar tidak terjadi pergesaran nilai-nilai dan mampu bersesuaian dengan penggunanya.

Pengintegrasian budaya dan kearifan lokal dalam pembelajaran bahasa Indonesia bagi pentur asing perlu dilakukan. Hal ini sebagai langkah strategis pengajar untuk mempermudah mahasiswa dalam mengenal dan memelajari bahasa Indonesia yang dikaitkan dengan budaya dan kearifan lokal Indonesia. Mahasiswa atau penutur asing yang belajar bahasa Indonesia pada tujuan akhirnya bermuara pada interaksi dengan masyarakat sehingga belajar bahasa Indonesia pun pada akhirnya lebih efektif jika dibersamai dengan belajar budaya dan kearifan lokal masyarakat Indonesia. Dengan demikian, Kearifan lokal atau local wisdom dapat dipahami sebagai gagasan-gagasan setempat (bersifat lokal) yang penuh rasa bijaksana, penuh kearifan, bernilai baik, yang tertanam dan diikuti oleh anggota masyarakatnya[7].

Peran integrasi budaya dan kearifan lokal dalam pembelajaranbahasa Indonesia bagi penutur asing yakni mampu meningkatkan daya tarik penutur asing dalam mempelajari bahasa Indonesia. Kekayaan budaya yang ada di Indonesia dapat dijadikan ilustrasi yang relevan dengan kebutuan pebelajar BIPA di Indonesia. Misalnya, hal itu dapat dilkukan dengan mengenalkan peninggalan budaya dan sejarah bangsa Indonesia yang berupa candi atau bangunan-bangunan bersejarah di Indonesia yang ditunjang dengan teks deskripsi yang jelas[8]. Indonesia juga kaya akan budaya kuliner makanan khas yang beraneka ragam sehingga juga dapat dijadikann contoh nyata dalam mempelajari kosa kata dalam bahasa Indonesia.

Penyusunan materi pembelajaran tematik berbasis budaya dan kearifan lokal perlu dilakukan dengan mengedepankan aspek tematik dan praktis. Penutur asing lebih antusias terhadap materi pembelajaran yang mengusung tema khusus seperti satu wujud budaya asli Indonesia. Selain itu, aspek praktis juga penting dikedepankan dalam penyelenggaraan pembelajaran Bahasa Indonesia bagi penutur asing. Praktis mengandung makna bahwa pembelajaran bahasa Indonesia harus mudah diterima, dimengerti, dan dimaknai secara komprehensif bagi mahasiswa BIPA karena menggunakan strategi integratif[9]. Pembelajaran integratif ini menurut pengalaman penulis sebagai pengajar BIPA lebih dari dua dekade menunjukkan hasil yang sangat signifikan. Dengan pembelajaran 50 jam di kelas, pembelajar dapat menguasai bahasa Indonesia tingkat dasar. Dengan pembelajaran integratif tersebut, pembelajar menguasai aspek-aspek penguasaan bahasa serta tata bahasa Indonesia tingkat dasar.

Konteks komunikasi tidak dapat dipisahkan dari konteks bahasa dan budaya. Konteks dari bahasa mengarah ke konteks pidato pada waktu itu yang mencakup aspek identitas peserta, waktu dan tempat pembicaraan, topik pembicaraan, dan tujuan pembicaraan percakapan. Dalam konteks budaya ini diketahui bahwa penggunaan bahasa oleh penutur adalah selalu berpola dan dipengaruhi oleh budaya sebagai latar belakang pembicara. Konteks budaya ini konteks yang relatif umum di masyarakat[10]. Aspek budaya juga merupakan salah satu dari 
lima standar dominasi bahasa asing termasuk dalam pengajaran bahasa Indonesia bagi penutur asing.

Pengajaran bahasa Indonesia bagi penutur asing memiliki kedudukan strategis dalam hal memperkenalkan bahasa dan budaya Indonesia kepada masyarakat internasional. Hal tersebut disebabkan selain sebagai lembaga pengajaran bahasa Indonesia, BIPA juga berperan untuk memberikan informasi tentang Indonesia yang meliputi kehidupan masayarakat dan budayanya. Dampaknya, menimbulkan rasa saling mengerti dan menghargai yang dapat meningkatkan hubungan kerjasama antarbangsa. Oleh karena itu, program BIPA layak dipandang sebagai media dan strategi diplomasi kebudayaan[11]. Pada praktiknya, sebelum memberikan pembelajaran struktur bahasa Indonesia, pemelajar BIPA terlebih dahulu dikenalkan pengetahuan tentang budaya-budaya lokal di Indonesia. Di dalam tataran praktis, pengorganisasian materi pembelajaran otentik ini diperlukan penekanan pada materi yang mambantu dalam menangkap kosakata, menyusun kalimat, memahami lawan bicara, memahami emosi diri, serta cara mengekspresikan suatu konsep bahasa dalam konteks komunikasi. Misalnya, pembelajaran berdiskusi tentang berita di koran di Indonesia, rekaman berita budaya di Indonesia, rekaman iklan, atau percakapan dalam drama merupakan media yang menarik untuk metode pembelajaran berbasis budaya. Budaya dan kearifan lokal tersebut juga mencakup sistem nilai dan norma, sosial, produk budaya, dan pengaplikasiannya dalam tindakan berbahasa. Hal itu mampu menciptakan kegiatan pendidikan yang sinergis dan bermakna karena tidak hany aberproses di dalam kelas tetapi juga praktik di luar kelas[12]. Dengan demikian, tujuan pendidikan dan tujuan pembelajaran bahasa Indonesia bagi penutur asing bisa berjalan optimal dan menghasilkan sesuatu yang baik [13].

\section{SIMPULAN}

Integrasi budaya dan kearifan lokal yang ada di Indonesia mampu bersinergi dengan pembelajaran bahasa Indonesia bagi penutur asing (BIPA). Tujuan dari pembelajaran BIPA mengandung tiga aspek penting, yaitu pengetahuan berbahasa, sikap berbahasa, dan ketrampilan berbahasa. Pemelajar BIPA dapat berkomunikasi dengan baik dan benar jika mereka paham dengan aspek-aspek sosial budaya masyarakat Indonesia. Pengetahuan tentang budaya mengajari mereka sistem tata krama, nilai, dan adat yang menghindarkan pemelajar BIPA dari risiko terjadinya benturan budaya dengan masyarakat, mengingat pemelajar BIPA akan melakukan interki secara langsung dengan masyarakat.

\section{REFERENCES}

[1]. Permendikbud Nomor 27 Tahun 2017 Tentang Penyelenggaranaan Program Pelatihan BIPA di Indonesia.

[2]. Undang-Undang Republik Indonesia Nomor 12 Tahun 2012 Tentang Implementasi Pendidikan di Perguruan Tinggi.

[3]. Saddhono, K. Integrating culture in Indonesian language learning for foreign speakers at Indonesian universities. Journal of Language and Literature, 6(2), 273-276. 2015.

[4]. Budiana, N. B., Indrowaty, S. A., \& Ambarastuti, R. D. Pengembangan Buku Teks BIPA Berbasis Multikulturalisme bagi Penutur Asing Tingkat Pemula. Diglossia: Jurnal Kajian Ilmiah Kebahasaan dan Kesusastraan, 9(2), 108-122. 2018.

[5]. Sutama. Metode Penelitian Pendidikan Kuntitaif, kualtatif, PTK, dan R\&D. Bandung: Remaja Rosdakarya. 2012. 
[6]. Wibowo, Agus. Pendidikan Karakter Berbasis Kearifan Lokal di Sekolah. Yogyakarta: Pustaka Pelajar. 2015.

[7]. Istiawati, F.N. Pendidikan Karakter Berbasis Nilai-Nilai Kearifan Lokal Adat Ammatoa dalam Menumbuhkan Karakter Konservasi. Cendikia, 10(1): 1-18. 2016.

[8]. Mussaif, Moh. Muzakka. Internasionalisasi Bahasa Indonesia sebagai Upaya Pemartabatan Bangsa. Makalah Kongres Bahasa Indonesia X di Hotel Grand Sahid Jaya, 28-31 Oktober 2013. 2013.

[9]. Meliono, I. Understanding The Nusantara Thought and Lokal Wisdom as an Aspect of The Indonesian Education. International Journal for Historycal Studies, 2(2): 221-234. 2011.

[10]. Levinson, et al. Politeness: Some Universal in Language Usage. Cambridge: Cambridge University Press. 2000.

[11]. Syairi, Khairi Abu. Pembelajaran Bahasa dengan Pendekatan Budaya. Jurnal Dinamika Ilmu, Vol.13. Nomor 2. p.180. 2013.

[12]. S. Tharayil, M. Borrego, M. Prince, K. A. Nguyen, P. Shekhar, C. J. Finelli, and C. Waters. "Strategies to Mitigate Student Resistance to Active Learning". International journal of STEM Education, Vol. 5, No. 1, pp. 7, 2018.

[13]. K. Saddhono, "Cultural and Social Change of Foreign Students in Indonesia: The Influence of Javanese Culture in Teaching Indonesian to Speakers of Other Languages (TISOL)," in IOP Conference Series: Earth and Environmental Science, 2018, vol. 126, no. 1. 